\title{
The Effect of an Educational Program on the Knowledge Level of Menopause
}

\author{
Bir Eğitim Programının Menopoz Bilgi Düzeyine Etkisi \\ Yeliz Kaya ${ }^{1}$, Dilek Şayık ${ }^{2}$, Muzaffer Bilgin ${ }^{3}$ \\ ${ }^{1}$ Eskişehir Osmangazi University Faculty of Health Sciences, Department of Gynecology and Obstetrics Nursing, Eskişehir, Turkey \\ ${ }^{2}$ Specialist Nurse, Eskisehir City Hospital, Department of Education, Eskişehir, Turkey \\ ${ }^{3}$ Eskişehir Osmangazi University Faculty of Medicine, Department of Biostatistik, Eskişehir, Turkey
}

\begin{abstract}
Introduction: The aim of this study was to determine the effect of an educational program on the knowledge level of symptoms and attitudes about menopause.

Methods: The questionnaire forms and health scales were completed by 36 women aged between 40 and 65 years before and after the education program. Following this education, women were encouraged to perform a self-examination of breasts (SEB) and self-examination of the vulva (SEV).

Results: The mean age of the women was $50.66 \pm 4.45$ and that the mean menopause age was $47.60 \pm 3.45$. The most frequently described symptom was fatigue $(91.7 \%)$. It was seen after the training that the Menopause Rating Scale (MRS) and the PSQI score decreased and the mean Quality of Life (SF-36) scale score increased. All these changes were statistically significant. As a result of SEB and SEV performed by the women after the education, it was found that $5.6 \%$ of the women had a breast deformity, $8.3 \%$ had a palpable mass in the breast, and that $13.9 \%$ detected vaginal discharge in the vulva examination $(\mathrm{p}<0.05)$.

Conclusion: Menopause could become easier to overcome with specific educational training programs prepared and given by health professionals, especially nurses. As a result, women will be able to cope with symptoms more effectively.
\end{abstract}

Key words: Menopause, woman, education

\section{INTRODUCTION}

During menopause, low estrogen levels can lead to vasomotor and genitourinary symptoms, and metabolic and structural changes such as osteopenia, osteoporosis, skin thinning, and an increase of adipose tissue content in breasts (1). Furthermore, due to estrogen deficiency, the atrophy in various tissues, regression of secondary sex characteristics, thinning of the epithelium and a loss

\section{ÖZET}

Giriş: Bu çalışmanın amacı, bir eğitim programının menopoza ilişkin belirti ve tutumların bilgi düzeyine etkisini belirlemektir. Yöntemler: Anket formları ve sağlık ölçekleri, eğitim programı öncesi ve sonrasında yaşları 40-65 arasında değişen 36 kadına doldurulmuştur. Bu eğitimin ardından kadınların kendi kendine meme muayenesi (KKMM) ve kendi kendine vulva muayenesi (KKVM) yapmaları teşvik edildi.

Bulgular: Kadınların yaş ortalaması $50.66 \pm 4.45$, ortalama menopoz yaşı $47.60 \pm 3.45$ idi. En sık tanımlanan semptom yorgunluktu (\%91,7). Eğitim sonrasında Menopoz Semptomlarını Değerlendirme ölçeği ve PUKİ puanının düştüğü, Yaşam Kalitesi (SF-36) ölçeği puan ortalamasının arttığı görüldü. Tüm bu değişiklikler istatistiksel olarak anlamlıydı. Kadınların eğitim sonrası yaptıkları KKMM ve KKVM sonucunda, kadınların $\% 5.6$ 'sında meme deformitesi, \%8.3'ünde memede ele gelen kitle, $\% 13,9$ 'unda vulva muayenesinde vajinal akıntı tespit edildi $(p<0.05)$.

Sonuç: Başta hemşireler olmak üzere sağlık profesyonelleri tarafından hazırlanan ve verilen özel eğitim programları ile menopozun atlatılması daha kolay hale getirilebilir. Sonuç olarak, kadınlar semptomlarla daha etkili bir şekilde baş edebileceklerdir.

Anahtar Kelimeler: Menopoz, kadın, eğitim

of rugae in the vagina, shortening of vaginal length, and decreased elasticity and decreased lubrication in the case of sexual stimuli can be seen (2). Sleep problems are one of the other most important symptoms affecting the health of women in the menopausal period (3).

The complaints of women during menopause are affected by educational status, age, occupation, economic independence, income level, marital 
adjustment, marital status, orientation to other fields, family size, status of receiving period-specific information, role change, and the values attributed to women by society (4). To overcome their complaints, women should feel that there are not alone during this period and be informed by structured educational programs prepared and given by health professionals. In this study, we aimed to determine the effect of such an educational program on the knowledge level of symptoms and attitudes about menopause and to teach women about the selfexamination of breasts (SEB) and self-examination of the vulva (SEV).

\section{METHODS}

The research was designed as a quasi-experimental study based on the pretest-posttest model which was carried out between May 24 and June 28, 2018 by the menopause school in a hospital in the province of Eskisehir, Turkey, after obtaining approval from the ethics committee and the necessary institutional permit.

Posters were first displayed for the menopause education one month before the course was to begin and brochures were distributed at the hospital to inform women about the education. During the enrollment period, women were informed about the subject, purpose, and methods of the research. Women were included in the study after taking their informed consent.

The admission conditions of the menopause school were that the women must be aged between 40 and 65 , who had started to have menopausal complaints, and were in the menopausal or post-menopausal period. The sample of our research consists of 36 women who had applied to the menopause school in 2018 and continued their education for 5 weeks.
They had not been diagnosed with a long-term sleep disorder and all 36 agreed to participate in the study.

\section{Data Collection Tools Used in the Research:} The data were collected by the researchers via survey technique in face-to-face interviews. The women, who continued to attend the menopause school, were asked to fill in the Socio-demographic Characteristics Determination Form which was prepared by the researcher in line with the literature, the Menopause Rating Scale, and the Pittsburgh Sleep Quality Index before the training. After the forms were completed, the women were given visual and applied training. After the training, the women were asked to complete the same forms again and were able to perform the Self-Examination of Breasts (SEB) and Self-Examination of the Vulva (SEV). The data were then analyzed, and the results were evaluated.

\section{Socio-demographic}

Characteristics

Determination Form: The form was prepared by the researchers in line with the literature and consisted of questions regarding age, marital status, educational level, income status, presence of chronic disease, and menopausal signs and symptoms.

Menopause Rating Scale (MRS): The scale has a Likert-type rating system consisting of 11 items regarding menopausal complaints. Each item is rated as 0: No symptoms, 1: Mild, 2: Moderate, 3: Marked and 4: Severe. The total score of the scale is calculated as the sum of scores given for each item. The minimum score that can be obtained from the scale is 0 and the maximum score is 44 . The 11 -item scale regarding menopausal complaints consists of 3 subdimensions. These subdimensions are 1- 
Somatovegetative complaints (items 1,2,3,11), 2Psychological complaints (items 4,5,6,7), and 3Urogenital complaints (items 8,9,10). The increase in the total scale score indicates an increase in the severity of complaints and thus indicates that the quality of life is negatively affected. In the original text of the MRS, it is stated that a score of "35 points and over" indicates that the symptoms are severe, a score between "20 to 34 points" indicates marked symptoms, a score between "15 and 19 points" indicates moderate symptoms, and a score between "1 and 14 points" indicates that there are no symptoms.

Pittsburgh Sleep Quality Index (PSQI): PSQI is a self-report scale consisting of 19 items that evaluates sleep quality and disorder in the past month. It consists of 24 questions including 19 selfreport questions and 5 questions to be answered by the spouse or a roommate. Eighteen questions scored on the scale consist of 7 components which are Subjective Sleep Quality, Sleep Latency, Sleep Duration, Habitual Sleep Efficiency, Sleep Disturbance, Use of Sleeping Medication, and Daytime Dysfunction. Each component is rated between 0 and 3 points. The sum of the scores from these 7 components gives the total scale score. The total score ranges between 0 to 21 points. A total score over 5 points indicates "poor sleep quality".

Quality of Life (SF-36) Scale: In this scale, health is evaluated in 8 components. The SF-36 scale consists of physical functioning (limited physical activity due to health problems), physical role (limited daily life activities due to health problems), bodily pain, general health (self-assessment of health), energy, general mental health, social functioning, and emotional role (limited daily activities due to mental health problems). The SF-36 scale is scored over 100 points and the score varies between 0 and 100 points for each component. On this scale, high scores indicate a better health level, while low scores indicate a deterioration in health.

Training program: Women who applied to the menopause school received training for a total of ten hours over five weeks. This was delivered by faculty members, physicians, nurses, dieticians, and psychologists in the training hall in five weekly twohour sessions. Menopause, premenopausal period, menopausal period, postmenopausal period, cycle in menopause, vasomotor, emotional changes and changes in the urinary system were topics covered in the first week. Changes in vulva and vagina, in ovaries and pelvic floor, in sexual life, in breasts and skin, and in the musculoskeletal, cardiovascular, and digestive systems were covered in the second week. Diagnosis, gynecological examination, laboratory tests, bone densitometry, ultrasound, mammography, treatment, hormone replacement therapy, alternative therapies, proper nutrition in menopause, calcium intake and sufficient fluid intake were covered in the third week. Stress coping methods, adequate sleep, social support, coping with vasomotor and skin changes, maintenance of self-esteem and protection from pregnancy were topics covered in the fourth week. Activity in menopause, Kegel exercises, Menopause exercises, SEB and SEB Practice, and SEV and SEV Practice were covered in the fifth week.

Evaluation of Data: Continuous data are given as mean \pm standard deviation and categorical data as a percentage (\%). The dependent sample t-test was 
Table 1. Frequency of Menopausal Symptoms

\begin{tabular}{|c|c|c|c|c|c|c|}
\hline \multirow[t]{2}{*}{ Changes } & \multirow[t]{2}{*}{ Symptoms } & \multicolumn{2}{|c|}{ I had / I have } & \multicolumn{2}{|c|}{$\begin{array}{l}\text { I did not have } \\
\text { / I do not have }\end{array}$} & \multirow[t]{2}{*}{$\mathbf{p}$} \\
\hline & & $\mathbf{n}$ & $\%$ & $\mathbf{n}$ & $\%$ & \\
\hline \multirow{10}{*}{ Vasomotor Changes } & Hot flushes & 31 & 86.1 & 5 & 13.9 & \multirow{10}{*}{$<0.001$} \\
\hline & Night sweating & 27 & 75.0 & 9 & 25.0 & \\
\hline & Redness of the face and neck & 27 & 75.0 & 9 & 25.0 & \\
\hline & Nausea & 8 & 22.2 & 28 & 77.8 & \\
\hline & Dizziness & 11 & 30.6 & 25 & 69.4 & \\
\hline & Headache & 15 & 41.7 & 21 & 58.3 & \\
\hline & Palpitation & 17 & 47.2 & 19 & 52.8 & \\
\hline & Sweating & 30 & 83.3 & 6 & 16.7 & \\
\hline & Feeling cold & 27 & 75.0 & 9 & 25.0 & \\
\hline & Tingling in hands and feet & 26 & 72.2 & 10 & 27.8 & \\
\hline \multirow{9}{*}{ Emotional Changes } & Nervousness & 29 & 80.6 & 7 & 19.4 & \multirow{9}{*}{$<0.001$} \\
\hline & Intense anxiety & 26 & 72.2 & 10 & 27.8 & \\
\hline & Depression & 22 & 61.1 & 14 & 38.9 & \\
\hline & Insomnia & 27 & 75.0 & 9 & 25.0 & \\
\hline & Fatigue & 33 & 91.7 & 3 & 8.3 & \\
\hline & Restless & 27 & 75.0 & 9 & 25.0 & \\
\hline & Weakness & 31 & 86.1 & 5 & 13.9 & \\
\hline & Drowsiness & 9 & 25.0 & 27 & 75.0 & \\
\hline & Forgetfulness & 19 & 52.8 & 17 & 47.2 & \\
\hline \multirow{8}{*}{ Physiological Changes } & Itching in the vulva & 5 & 13.9 & 31 & 86.1 & \multirow{8}{*}{0.002} \\
\hline & Painful sexual intercourse & 15 & 41.7 & 21 & 58.3 & \\
\hline & Frequent urination & 13 & 36.1 & 23 & 63.9 & \\
\hline & Uterine prolapse & 2 & 5.6 & 34 & 94.4 & \\
\hline & Urinary incontinence (stress) & 8 & 22.2 & 28 & 77.8 & \\
\hline & Constipation & 8 & 22.2 & 28 & 77.8 & \\
\hline & Osteoporosis & 6 & 16.7 & 30 & 83.3 & \\
\hline & Skin distortions & 13 & 36.1 & 23 & 63.9 & \\
\hline
\end{tabular}

* Pearson Exact Chi-Square

used in order to test the significance of the difference between the arithmetic means of the two related groups and the Pearson Chi-Square analysis was used in the analysis of the cross tables. The IBM SPSS Statistics 21.0 (IBM Corp. Released 2012. IBM SPSS Statistics for Windows, Version 21.0. Armonk, NY: IBM Corp.) program was used for the analyses. Statistical significance was accepted as $p<0.05$.

\section{Ethical Aspect of the Study}

Approval for the study was obtained from the ethics committee (date: 29.01.2018 no: 80558721/G-24-
E.46292) from Eskişehir Osmangazi University, and the institution (date: 08.11.2017. no: 28345697-799E.2180) from Eskişehir Provincial Health Directorate. Only voluntary women whose written consents were obtained were included in the study.

\section{RESULTS}

The mean age of the women was $50.66 \pm 4.45$ (min:42, max:61) and the mean marriage duration was $26.94 \pm 7.01$ (min:5, max:41) years. It was determined that $100 \%$ of the women lived in the city center, $91.7 \%$ were married, $88.9 \%$ had social security insurance from government, and that $91.7 \%$ 
had a nuclear family. It was found that $50.0 \%$ of the women had a chronic disease. In addition, the mean menopausal age was 47.60 \pm 3.45 ( $\min : 37$, max:56).

The most frequently described symptoms were fatigue $(91.7 \%)$, weakness and hot flushes (86.1\%), sweating (83.3\%), nervousness (80.6\%). In addition, the least described symptoms in the menopausal period were uterine prolapse $(5.6 \%)$, itching in the vulva (13.9\%), and osteoporosis (16.7\%). The frequency of vasomotor, emotional, and physiological changes of the women in the menopausal period was found to be significant $(p<0.05)$ (Table 1).

After the training, the mean MRS score of the women who participated in the study decreased from $16.83 \pm 8.87$ to $13.66 \pm 8.36$, and the mean PSQI score decreased from $14.34 \pm 2.64$ to $13.81 \pm 2.55$. This difference in the means was found to be statistically significant $(p<0.05)$. Furthermore, the mean Quality of Life (SF-36) scale score increased from $48.74 \pm 19.13$ to $54.92 \pm 17.40$ after the training, and this difference was found to be highly significant $(p<0.001)$ (Table 2).

In the study, it was found that $77.7 \%$ of the women performed a self-examination of breasts and the mean frequency of SEB was once in every $9.67 \pm 9.30$ (min:1, max:36) months. It was determined that $94.4 \%$ of the women had breast ultrasonography, $88.8 \%$ had mammography, and $88.8 \%$ had a pap-smear test. All women performed SEB and SEV after the training. In the visual breast examination, $5.6 \%$ of the women detected breast deformity, $8.3 \%$ detected a palpable mass during breast palpation, and $13.9 \%$ detected vaginal discharge in the visual vulva examination (Table 3 ).

\section{DISCUSSION}

Premenopausal, menopausal, and postmenopausal periods constitute a large part of a woman's life. In the literature, similar to the results of our study, the most frequent symptoms in the menopausal period were hot flushes and sweating, physical and mental fatigue, anxiety, and sleep problems (5). However, with the physiological changes that develop during this long period in women's lives, women can experience many negative experiences. The high frequency of women experiencing menopausal complaints in the menopausal period, and these unpleasant experiences, negatively affect the quality of life.

It was determined that the women in our study experienced had "moderate" menopausal symptoms (mean: 16.83 \pm 8.87 ) before the training and "mild" symptoms (mean: 13.66 \pm 8.36 ) after the training. Our study suggested that women have a lack of information about menopause based on the fact that there was a significant decrease in the mean MRS scores of the women after the training. It can be said that the health training we provided increased the knowledge of women about menopause, enabled them to experience fewer menopausal symptoms, and made a positive change to the quality of life and sleep.

In a study conducted in China, it was seen that the PSQI scores were greater than 8 in women in menopause (6). In a study conducted in Canada, women in menopause received cognitive-behavioral treatment, in which cognitive and behavioral strategies were applied together with psychoeducation, and it was reported that there was an effective improvement in sleep disturbance value $(p<0.001)$ (7). In our study, the PSQI scores decreased from $14.34 \pm 2.64$ to $13.81 \pm 2.55(p<0.05)$ after training, although sleep quality could not reach the 
Table 2. Pre-Training and Post-Training Mean Menopause Rating Scale (MRS), Pittsburgh Sleep Quality Index (PSQI), and Quality of Life (SF-36) Scale Scores

\begin{tabular}{|c|l|c|c|c|c|}
\hline $\begin{array}{c}\text { Name of } \\
\text { Scale }\end{array}$ & \multicolumn{1}{|c|}{ Subdimensions of Scale } & $\begin{array}{c}\text { Pre-Training } \\
\text { Mean } \pm \text { SD }\end{array}$ & $\begin{array}{c}\text { Post-Training } \\
\text { Mean } \pm \text { SD }\end{array}$ & $\mathbf{t}$ & $\mathbf{p}$ \\
\hline \multirow{4}{*}{ MRS } & Somatovegetative Complaints & $6.08 \pm 3.49$ & $4.91 \pm 3.33$ & 5.48 & $<0.001$ \\
& Psychological Complaints & $6.58 \pm 3.50$ & $5.00 \pm 3.09$ & 6.25 & $<0.001$ \\
& Urogenital Complaints & $4.16 \pm 2.34$ & $3.75 \pm 2.45$ & 3.10 & $<0.001$ \\
& \multicolumn{1}{|c|}{ Total Score } & $\mathbf{1 6 . 8 3 \pm 8 . 8 7}$ & $\mathbf{1 3 . 6 6 \pm 8 . 3 6}$ & $\mathbf{6 . 3 5}$ & $<\mathbf{0 . 0 0 1}$ \\
\hline \multirow{4}{*}{ PSQI } & Subjective Sleep Quality & $1.75 \pm 0.64$ & $1.58 \pm 0.55$ & 2.64 & 0.012 \\
& Sleep Latency & $2.91 \pm 1.48$ & $2.16 \pm 1.13$ & 4.18 & $<0.001$ \\
& Sleep Duration & $7.64 \pm 1.36$ & $8.01 \pm 1.30$ & -1.96 & 0.047 \\
& Habitual Sleep Efficiency & $0.69 \pm 1.16$ & $0.96 \pm 0.99$ & 3.88 & 0.043 \\
& Sleep Disturbance & $1.69 \pm 0.57$ & $1.47 \pm 0.51$ & 3.16 & 0.003 \\
& Use of Sleeping Medication & $0.38 \pm 0.83$ & $0.22 \pm 0.48$ & 2.64 & 0.012 \\
& Daytime Dysfunction & $0.75 \pm 0.80$ & $0.59 \pm 0.63$ & 2.43 & 0.031 \\
& & $\mathbf{1 4 . 3 4 \pm 2 . 6 4}$ & $\mathbf{1 3 . 8 1 \pm 2 . 5 5}$ & $\mathbf{2 . 2 5}$ & $\mathbf{0 . 0 3 0}$ \\
\hline \multirow{5}{*}{ SF-36 } & $66.66 \pm 19.63$ & $70.69 \pm 17.97$ & -2.89 & $<0.001$ \\
& Physical Functioning Score & $38.88 \pm 42.86$ & $44.44 \pm 44.36$ & -1.75 & 0.088 \\
& Physical Role & $40.95 \pm 46.50$ & $47.61 \pm 48.02$ & -1.64 & 0.109 \\
& Emotional Role & $46.94 \pm 14.89$ & $52.36 \pm 11.86$ & -4.63 & $<0.001$ \\
& Energy/Vitality & $51.88 \pm 12.98$ & $56.88 \pm 11.59$ & -5.20 & $<0.001$ \\
& General Mental Health & $51.73 \pm 20.29$ & $56.59 \pm 15.94$ & -3.20 & $<0.001$ \\
& Social Functioning & $54.30 \pm 20.10$ & $59.72 \pm 16.19$ & -3.98 & $<0.001$ \\
& Bodily Pain & $39.72 \pm 17.64$ & $46.25 \pm 14.65$ & -4.16 & $<0.001$ \\
& General Health & $\mathbf{4 8 . 7 4 \pm 1 9 . 1 3}$ & $\mathbf{5 4 . 9 2 \pm 1 7 . 4 0}$ & $\mathbf{- 4 . 2 4}$ & $<\mathbf{0 . 0 0 1}$ \\
\hline
\end{tabular}

* Dependent Sample t-Test

desired level with short-term training as this value remained over 5 points.

As a result, it is clear that menopausal symptoms disturb women's sleep quality. In order to increase sleep quality, it is recommended that long-term training on menopause, or the implementation of alternative interventions, be planned.

Menopausal symptoms can damage the quality of life of women. In accordance with the literature, it was determined that the quality of life was negatively affected in women with a negative menopause attitude (8). Women should be professionally supported to protect the quality of life during menopause and to ensure the sustainability of this protection. The planned health training could be a highly useful tool to overcome the menopause and its symptoms. In a study, women received training on menopause for 5 weeks and the rate of women with a positive attitude towards menopause increased from $51.6 \%$ to $85.5 \%$ after the training $(p<0.001)(9)$. In the study by Kucukcakir et al. (2013), women with postmenopausal osteoporosis received a supervised Pilates exercise program twice a week for a year and it was found that there was a significant increase in the women's quality of life by the end of the program (10). In our study, the women in the menopause school received training from healthcare professionals for 5 weeks and after the training the mean Quality of Life (SF-36) Scale score of the women increased from $48.74 \pm 19.13$ to $54.92 \pm 17.40(p<0.001)$. As a result, with the structured training in our menopause school, positive changes were achieved in sleep quality, quality of life, and in the menopause rating scale. It could be determined that women can have a positive attitude towards menopause and their quality of life can be improved when they are professionally supported during the menopausal process. 
Table 3. Findings regarding Self-Examination of Breasts and Self-Examination of the Vulva After the Training

\begin{tabular}{|l|l|l|cc|cc|}
\hline $\begin{array}{c}\text { Name of } \\
\text { Examination }\end{array}$ & \multicolumn{1}{|c|}{$\begin{array}{l}\text { Examination } \\
\text { Method }\end{array}$} & \multicolumn{1}{|c|}{ Examination Result } & \multicolumn{2}{c|}{ Present } & \multicolumn{2}{c|}{$\begin{array}{c}\text { Not Present } \\
\mathbf{n}\end{array}$} \\
\hline \multirow{4}{*}{ SEB } & Visual & Breast Deformity & 2 & 5.6 & 34 & 94.4 \\
& Examination & Color Change & 0 & 0.0 & 36 & 100.0 \\
& Palpation & Presence of Palpable Mass in Breasts & 3 & 8.3 & 33 & 91.7 \\
& Presence of Axillary Mass & 0 & 0.0 & 36 & 100.0 \\
\hline \multirow{3}{*}{ SEV } & Visual & Vulva Deformity & 0 & 0.0 & 36 & 100.0 \\
& Examination & Presence of Vaginal Discharge & 5 & 13.9 & 31 & 86.1 \\
& Palpation & Presence of Palpable Mass in Vulva & 0 & 0.0 & 36 & 100.0 \\
\hline
\end{tabular}

It is known that performing SEB and SEV will increase the ability to detect problems in breasts or the vulva and if a disease is detected in the examined area, the process will be positively affected. Therefore, women should be informed about the importance of selfexamination by healthcare professionals for early diagnosis. In the literature, it can be seen that the rate of women performing SEB varied between $15.8 \%$ and $79 \%(11)$, and that the rate of performing SEV varied between $3.1 \%$ and $55.9 \%(11,12)$. In our study, before the training, although women had not performed SEB regularly each month, it was found that $77.7 \%$ of women performed SEB $(9.67 \pm 9.30$ months on average) none of them had performed SEV. After the training of SEB and SEV, all women performed these selfexamination methods. In the visual breast examination, $5.6 \%$ of women detected breast deformity. In palpation, $8.3 \%$ of the women detected a palpable mass in the breast. In the visual vulva examination, $13.9 \%(p<0.05)$ of the women detected a vaginal discharge. As a result, the possible malignancies could be avoided by early diagnosis with these self-examination methods.

The main limitation of the research was that only women who applied to the menopause school that we organized were enrolled to the study.

\section{CONCLUSION}

Complaints of women during menopause are affected by many factors. However, how they receive information, their role changes, and the value attributed to women by society may also affect these complaints. Menopause could become easier to overcome with specific comprehensive training programs which enable women to cope with symptoms more effectively.

Women should be supported by structured and comprehensive training by healthcare professionals in order to enable them to cope with the symptoms experienced during the menopausal transition period. Nurses who spend a long time with patients and their relatives should conduct this process effectively to prevent the adverse impact on the quality of life of women in the menopausal period and so improve their quality of life. Nurses should provide counseling, care, and training services to women before and during this menopausal process.

Informed Consent: Informed consent was obtained from patients who participated in this study.

Conflict of Interest: None declared.

Financial Disclosure: Any company or institution has not financially contributed to the study.

\section{REFERENCES}

1. Atalay MA, Durusoy EE, Tüfekçi M. Should we give up hormone treatment in menopause? J Turk Soc Obstet Gynecol 2013;10: 242- 9.

2. Brown KH, Hammond CB. Urogenital atrophy. Obstet Gynecol Clin North Am 1987;15:13-32.

3. Moe KE. Menopause. In: Kryger MH, Roth T, Dement WC, editors. Principles and Practice of Sleep Medicine. Fourth edition, Philadelphia, Elsevier Saunders; 2005:1287-96. 
4. Ozcan H, Oskay U. Evidence-based practices in symptom management during menopause. Göztepe Tıp Dergisi 2013;28(4):15763

5. Palacios S, Henderson VW, Siseles N, Tan D, Villaseca P. Age of menopause and impact of climacteric symptoms by geographical region. Climacteric 2010:13(5):419-28.

6. Sun D, Shao H, Li C, Tao M. Sleep disturbance and correlates in menopausal women in Shanghai. J Psychosom Res 2014;76(3):23741.

7. Green SM, Donegan E, Frey BN, et al. Cognitive behavior therapy for menopausal symptoms (CBT-Meno): a randomized controlled trial. Menopause 2019;26(9):972-80.

8. Gumusay M, Erbil N. The effect of attitudes towards menopause on menopause specific quality of life of women. Ordu University $\mathrm{J}$ Nurs Stud 2019;2(2):96-109.
9. Gonenc I, Koc G. The effect of menopausal training program on women's attitudes of menopause. SDÜ Saglik Bilimleri Dergisi 2019;10(1):29-33.

10. Kucukcakir N, Altan L, Korkmaz N. Effects of Pilates exercises on pain, functional status, and quality of life in women with postmenopausal osteoporosis. Journal of Bodywork and Movement Therapies 2013;17(2):204-11.

11. Albayrak S, Catıker A. Evaluation of sexual behaviors of married women aged $15-49$ in Karaköy region. KU Tip Fak Derg 2011;13(1):30-4.

12. Aydogdu SGM, Bekar M. Determination of knowledge and behavior of university female students about gynecological cancer prevention. Türk Jinekolojik Onkoloji Dergisi, 2016:19(1): 25-32.

Cite as: Kaya Y, Şayık D, Bilgin M. The Effect of an Educational Program on the Knowledge Level of Menopause. Eskisehir Med J. 2021;2(3):158-165. 